\title{
FAKTOR YANG MEMPENGARUHI DANA DEPOSITO BANK UMUM SYARIAH DI INDONESIA TAHUN 2010-2015
}

\section{FACTORS AFFECTING THE DEPOSIT FUNDS OF SHARIA BANKS IN INDONESIA YEAR 2010-2015}

\author{
Dinan Izzan Abshari1a; Fatin Fadhilah Hasib² \\ 1aMahasiswa Program Studi S1 Ekonomi Islam-Fakultas Ekonomi dan Bisnis Universitas \\ Airlangga, E-mail: dinan-i-a-11@feb.unair.ac.id \\ ${ }^{2}$ Departemen Ekonomi Syariah- Fakultas Ekonomi dan Bisnis-Universitas Airlangga \\ E-mail: fatin.fadhilah@feb.unair.ac.id
}

(Diterima oleh Dewan Redaksi: 05-06-2018)

(Dipublikasikan oleh Dewan Redaksi: 30-06-2018)

\begin{abstract}
The goal of this research is to determine the factors that affecting Islamic Bank Deposits in Indonesia during the period of 2010-2015. The method of research used is the quantitative approach. The sample of the research is Islamic Bank in Indonesia which is taken every months for each variable during the period of 2010-2015. The analysis technique used is multiple regression analysis and the result is $\mathrm{Y}=2,123-0,111\left(\mathrm{X}_{1}\right)-$ $1,135\left(\mathrm{X}_{2}\right)+2,977\left(\mathrm{X}_{3}\right)$, with $\mathrm{R}^{2}$ registration 0,179 or $17,9 \%$. The result of the partial test shows that Consumer Price Index and Rate of Profit have significant effects and the Interest Rate has no significant effect partially on the Deposit Fund of Islamic Bank in Indonesia. The result of the simultaneous test shows that the three variables have significant effects to Islamic Bank Deposits in Indonesia.
\end{abstract}

Keywords: Islamic Bank Deposits, Consumer Price Index, Interest Rate, Rate of Profit.

\begin{abstract}
ABSTRAK
Tujuan dari penelitian ini adalah untuk mengetahui faktor-faktor yang mempengaruhi deposito Bank Syariah di Indonesia selama periode 2010-2015. Metode penelitian yang digunakan adalah pendekatan kuantitatif. Sampel penelitian adalah Bank Syariah di Indonesia yang diambil setiap bulan untuk setiap variabel selama periode 2010-2015. Teknik analisis yang digunakan adalah analisis regresi berganda dan hasilnya $\mathrm{Y}=2,123$ - 0,111 (X1) - 1,135 (X2) + 2,977 (X3), dengan koefisien determinasi berganda 0,179 atau 17,9\%. Hasil dari uji parsial menunjukkan bahwa Indeks Harga Konsumen dan Tingkat Keuntungan memiliki pengaruh yang signifikan dan Tingkat Bunga tidak memiliki pengaruh yang signifikan secara parsial terhadap Dana Deposito Bank Syariah di Indonesia. Hasil uji simultan menunjukkan bahwa ketiga variabel tersebut memiliki pengaruh signifikan terhadap deposito Bank Syariah di Indonesia.
\end{abstract}

Kata kunci: Deposito Bank Syariah, Indeks Harga Konsumen, Suku Bunga, Tingkat Keuntungan 
\begin{tabular}{l}
\hline Dinan Izzan Abshari. 2018. Faktor yang Mempengaruhi Dana Deposito Bank Umum \\
Syariah di Indonesia Tahun 2010-2015. Jurnal Nisbah 4 (1): 22-33.
\end{tabular}

\section{PENDAHULUAN}

Perbankan syariah merupakan perbankan yang beroperasi berdasarkan prinsip bagi hasil yang saling menguntungkan bagi masyarakat dan juga bank yang didukung dengan bermacam-macam produk dan skema keuangan yang lebih variatif (Antonio, 2001:29). Perbankan syariah lebih mengutamakan aspek keadilan dalam bertransaksi, investasi yang beretika, mengedepankan nilai-nilai kebersamaan dan persaudaraan dalam berproduksi, dan yang paling penting menghindari kegiatan transaksi keuangan yang mengandung unsur riba. Hal ini sesuai dengan firman Allah SWT yang berbunyi:

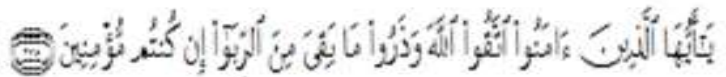

Artinya: "Hai orang-orang yang beriman, bertakwalah kepada Allah dan tinggalkan sisa Riba (yang belum dipungut) jika kamu orang-orang yang beriman." (Q.s Al Baqarah: 278, Depad RI, 2005)

Menurut Quraish Shihab dalam Tafsir Al-Misbah (2002: 597) ayat tersebut menjelaskan tentang perbedaan antara yang melakukan praktek riba, dengan yang beriman dan beramal saleh, melaksanakan shalat dan menunaikan zakat, maka sungguh tepat bila ayat ini mengundang orang-orang beriman yang selama ini masih memiliki keterkaitan dengan praktek riba agar segera meninggalkannya untuk menghindari siksa atau jatuhnya sanksi dari Allah.

Bank syariah memiliki fungsi sebagai perantara jasa keuangan (financial intermediary), yang mempunyai tugas pokok yaitu menghimpun dana dari masyarakat dan menyalurkan kembali kepada masyarakat dalam bentuk fasilitas pembiayaan hal ini sesuai dengan UU No. 7 tahun 1992 tentang perbankan sebagaimana telah diubah UU. No. 10 tahun 1998.

Perkembangan Bank Syariah di Indonesia ditandai dengan berdirinya Bank Mumalat Indonesia (BMI) pada tahun 1992 dan disebut sebagai perintis berdirinya bank syariah di Indonesia. Ascarya (2012: 205) menjelaskan bahwa penerapan sistem keuanga dan perbankan ganda mulai mengalami kejelasan setelah dikeluarkannya Undang-Undang Perbankan No. 10 Tahun 1998, sehingga setelah itu mulai bermunculan lembaga keuangan syariah yang beroperasi berdampingan dengan lembaga keuangan konvensional.

Bank Syariah mengumpulkan dana dari masyarakat dalam bentuk Dana Pihak Ketiga (DPK). DPK yang dihimpun akan dialokasikan untuk kegiatan yang diperbolehkan menurut syariah islam. DPK merupakan dana yang dipercayakan oleh masyarakat kepada bank berdasarkan perjanjian penyimpanan dana dalam bentuk giro, deposito, dan tabungan.

Deposito merupakan produk yang paling banyak diminati para nasabah karena tingkat pengembaliannya yang paling tinggi. Menurut Fatwa DSN nomor 3 Tahun 2000 menyatakan bahwa deposito yang dibenarkan dalam syariah adalah deposito yang berdasarkan prinsip mudharabah. Dalam transaksi deposito mudharabah, nasabah bertindak sebagai pemilik dana (shahibul maal) dan bank bertindak sebagai pengelola dana (mudharib).

Indeks Harga Konsumen adalah suatu ukuran keseluruhan biaya yang harus dibayar oleh seorang konsumen 
guna memperoleh barang dan jasa untuk memenuhi kebutuhan hidupnya (Mankiw, 2004:446).

Rate of profit merupakan konsep dimana ditentukan imbalannya kemudian sedangkan bunga pada dasarnya adalah konsep dimana ditentukan imbalan sebelumnya. Rate of profit merupakan kunci penting bagi bank syariah guna terciptanya keadilan ekonomi bagi pendapatan investasi dan kesejahteraan masyarakat dibandingkan dengan menggunakan sistem bunga (Supriyanto, 2015:179).

Keuntungan yang ditawarkan melalui bank syariah adalah bagi hasil sedangkan bank konvensional adalah suku bunga. Suku bunga (Interest Rate) merupakan pembayaran yang dilakukan atas penggunaan sejumlah uang dan Interest Rate merupakan jumlah interest yang dibayarkan per unit waktu atau orang harus membayar untuk kesempatan meminjam uang (Samuelson dan Nordaus, 1992:500). Jika tingkat suku bunga pada bank konvensional lebih tinggi dibandingkan dengan tingkat bagi hasil yang ditawarkan maka di khawatirkan nasabah yang awalnya merupakan nasabah bank syariah akan beralih menjadi nasabah bank konvensional dan sebaliknya jika tingkat bagi hasil lebih tinggi dibandingkan suku bunga bank konvensional maka bisa saja nasabah yang semula menjadi nasabah bank konvensional beralih menjadi nasabah bank syariah.

Berdasarkan penjelasan tersebut, maka penelitian ini dilakukan untuk mengetahui faktor yang mempengaruhi Deposito Bank Umum Syariah di Indonesia.

\section{MATERI DAN METODE}

\section{Bank Syariah}

Bank adalah badan usaha yang menghimpun dana dari masyarakat dalam bentuk simpanan dana mengeluarkannya kepada masyarakat dalam bentuk kredit, dan atau bentukbentuk lainnya dalam rangka meningkatkan taraf hidup rakyat banyak" (Undang-undang No 10 Tahun 1998 tentang Perbankan).

Bank Syariah merupakan bank yang mempunyai visi dan misi menjadi wadah terpercaya bagi masyarakat yang ingin melakukan investasi dengan sistem bagi hasil secara adil sesuai prinsip syariah. Bank Syariah adalah lembaga keuangan yang usaha pokoknya memberikan pembiayaan dan jasa - jasa lainnya dalam lalu lintas pembayaran serta peredaran uang yang pengoperasiannya disesuaikan dengan prinsip syariat islam (Muhammad, 2005:16).

\section{Karakteristik Perbankan Syariah}

Dalam menjalankan aktivitasnya, Bank Syariah menganut prinsip-prinsip sebagai berikut (Muhammad, 2005:78):

1. Prinsip Keadilan

Dengan sistem operasional yang berdasarkan profit and loss sharing system, bank Islam memiliki kekuatan tersendiri yang berbeda dari sistem konvensional. Perbedaan ini nampak jelas bahwa dalam sistem bagi hasil terkandung dimensi keadilan dan pemerataan. Apabila merujuk pada strategi keunggulan bersaing (competitive advantage-strategy) Michael Porter, maka sistem bagi hasil merupakan strategi diferensiasi yang menjadi kekuatan tersendiri bagi lembaga yang bersangkutan untuk memenangkan persaingan yang kompetitif.

2. Prinsip Kesederajatan

Bank Syariah menempatkan nasabah penyimpan dana, nasabah pengguna dana, maupun bank pada kedudukan yang sama dan sederajat. Hal ini tercermin dalam hak, kewajiban, risiko, dan keuntungan yang berimbang antara nasabah pengguna dana maupun 
bank. Dengan sistem bagi hasil yang diterapkannya, bank syariah mensyaratka adanya kemitraan nasabah harus sharing the profit and the risk secara bersama-sama.

3. Prinsip Ketentraman

Menurut falsafah Al-Quran, semua aktivitas yang dilakukan oleh manusia patut dikerjakan untuk mendapatkan falah (ketentraman, kesejahteraan dan kebahagiaan), yaitu istilah yang dimaksudkan untuk mencapai kesempurnaan dunia dan akhirat (Siddiqi, 1991:3). Tujuan dan aktivitas ekonomi dalam perspektif Islam harus diselaraskan dengan tujuan akhir yaitu pada pencapaian falah. Prinsip ini menghubungkan prinsip ekonomi dengan nilai moral secara langsung.

\section{Indeks Harga Konsumen (IHK)}

Indeks harga konsumen adalah suatu ukuran keseluruhan biaya yang harus dibayar oleh seorang konsumen guna memperoleh barang dan jasa untuk memenuhi kebutuhan hidupnya. Indeks harga konsumen menunjukkan biaya sekeranjang belanjaan barang dan jasa disuatu waktu dibandingkan dengan harga atau biayanya pada tahun dasar. Indeks ini digunakan untuk mengukur keseluruhan tingkat harga dalam suatu perekonomian (Mankiw, 2004: 446).

\section{Interest Rate}

Interest Rate atau yang biasa kita kenal dengan tingkat suku bunga merupakan harga dari pinjaman. Suku bunga dinyatakan sebagai persentase uang pokok per unit waktu. Bunga merupakan suatu ukuran harga sumber daya yang digunakan oleh debitur yang harus dibayarkan kepada kreditur (Sunariyah, 2004:80).

BI Rate adalah suku bunga kebijakan yang mencerminkan sikap atau stance kebijakan moneter yang ditetapkan oleh bank Indonesia dan diumumkan kepada publik (www.bi.go.id).

\section{Rate Of Profit}

Rate of profit merupakan kunci penting bagi bank syariah guna terciptanya keadilan ekonomi bagi pendapatan investasi dan kesejahteraan masyarakat dibandingkan dengan menggunakan sistem bunga. Rate of profit pembiayaan yang berkeadilan akan menghasilkan rate of profit yang adil bagi nasabah dana mudharabah dan bank sebagai pengelola (Supriyanto, 2015:179).

\section{Deposito Syariah}

Menurut Dendawijaya (2001:57) menjelaskan bahwa deposito atau simpanan berjangka adalah simpanan pihak ketiga pada bank yang penarikannya hanya dapat dilakukan dalam jangka waktu tertentu. Sedangkan deposito syariah adalah deposito yang dijalankan berdasarkan prinsip syariah sebagaimana yang telah difatwakan oleh Dewan Syariah Nasional MUI bahwa deposito yang dibolehkan oleh islam adalah deposito yang berdasarkan prinsip mudharabah yang termaktub dalam fatwa nomor 03/DSN-MUI/IV/2000.

Adapun dasar hukum Deposito Syariah berdasarkan akad mudharabah terdapat dalam Al-Qur'an dan Hadits. Allah SWT berfirman dalam Q.S. AlMuzammil ayat 20:

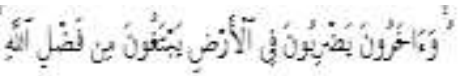

Artinya: "Dan orang-orang yang berjalan di muka bumi mencari sebagian karunia Allah. "( Q.S. 73 :20, Depag RI, 2005)

Dari Suhaib ra. bahwa Rasulullah SAW bersabda :

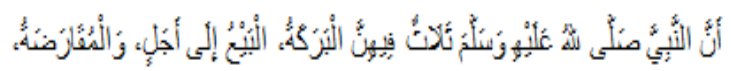

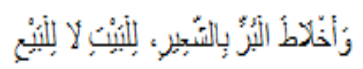

Artinya :" Tiga perkara didalamnya terdapat keberkatan (1) menjual dengan pembayaran secara kredit (2) muqaradhah (nama lain dari mudharabah) (3) 
mencampur gandum dengan tepung untuk keperluan rumah dan bukan untuk dijual." (HR. Ibnu Majah, Mardani, 2011 : 194)

Menurut ayat dan hadits diatas menjelaskan mudharib adalah sebagian dari orang-orang yang melakukan perjalanan untuk mencari karunia Allah SWT dari keuntungan investasinya. Investasi yang dilakukan yaitu investasi yang mengandung keberkatan didalamnya yaitu melalui akad mudharabah.

\section{Indeks Harga Konsumen Terhadap Deposito Bank Syariah}

Indeks Harga Konsumen (IHK) adalah indeks yang mengukur rata-rata perubahan harga antar waktu dari suatu paket jenis barang dan jasa yang dikonsumsi oleh penduduk atau rumah tangga di daerah perkotaan dengan dasar suatu periode tertentu (www.bps.go.id). Zainal et al (2009) menjelaskan bahwa IHK memiliki hubungan signifikan terhadap deposito rekening mudharabah. Jadi, jika IHK mengalami kenaikan maka deposito bank syariah akan mengalami penurunan yang nantinya berdampak pada penghimpunan dana bank syariah hal ini dikarenakan tingkat konsumsi masyarakat yang meningkat sehingga dana dari masyarakat tersebut lebih digunakan untuk kebutuhan sehari-hari dibandingkan ditempatkan pada bank.

\section{Interest Rate Terhadap Deposito Bank Syariah}

Interest rate adalah harga dari penggunaan uang untuk jangka waktu tertentu (Boediono, 1998: 75). Berdasarkan teori ekonomi klasik tabungan dan investasi merupakan fungsi bunga. Jika tingkat bunga naik, maka masyarakat akan cenderung untuk mendepositokan uangnya. Hal ini di dukung dengan penelitian yang dilakukan oleh Eriemo (2013) yang menyatakan bahwa suku bunga signifikan berpengaruh terhadap deposito bank negara Nigeria. Artinya, jika tingkat suku bunga naik maka masyarakat akan berlomba-lomba menempatkan uang pada produk deposito pada bank tersebut.

\section{Rate of Profit Terhadap Deposito Bank Syariah}

Rate of profit merupakan tingkat keuntungan yang sangat penting dalam ilmu keuangan karena fungsinya menilai aset keuangan. Berdasarkan teori segmentasi nasabah perbankan menjelaskan bahwa sebagian nasabah menaruh uangnya di bank dikarenakan alasan rasional ekonomi seperti tingkat keuntungan dan kualitas layanan yang ditawarkan. Keuntungan yang ditawarkan dalam perbankan adalah bagi hasil bagi bank syariah dan suku bunga bagi bank konvensional. Menurut Haron dan Ahmad (2000), rate of profit signifikan berpengaruh positif terhadap deposito bank syariah. Maka, jika tingkat keuntungan suatu bank meningkat maka deposito pada bank syariah akan meningkat dikarenakan nasabah yang banyak menempatkan dananya pada produk deposito tersebut.

Jenis Penelitian

Jenis penelitian yang digunakan adalah pendekatan kuantitatif. Penelitian ini akan membuktikan pengaruh Indeks Harga Konsumen, Interest Rate, dan Rate of Profit terhadap Deposito Bank Umum Syariah di Indonesia baik secara parsial maupun simultan.

\section{Identifikasi Variabel}

Variable bebas dalam penelitian ini adalah Indeks Harga Konsumen, Interest Rate, dan Rate of Profit. Sedangkan variabel terikatnya adalah dana Deposito Bank Umum Syariah di Indonesia.

Variabel-variabel yang digunakan tersebut definisi operasionalnya adalah sebagai berikut: 
1. Indeks Harga Konsumen $\left(\mathrm{X}_{1}\right)$

Merupakan indeks yang mengukur rata- rata perubahan harga antarwaktu dari suatu paket jenis barang dan jasa yang dikonsumsi oleh penduduk atau rumah tangga di daerah perkotaan dengan dasar suatu periode tertentu. Indeks Harga Konsumen dalam penelitian ini diperoleh dari laporan Badan Pusat Statistik yang telah di publish pada website resmi BPS dengan periode Januari 2010 hingga Desember 2015.

2. Interest Rate $\left(\mathrm{X}_{2}\right)$

Merupakan harga dari pinjaman. Suku bunga dinyatakan sebagai persentase uang pokok per unit waktu. Bunga merupakan suatu ukuran harga sumber daya yang digunakan oleh debitur yang harus dibayarkan kepada kreditur. Interest rate dalam penelitian ini diperoleh dari laporan BI Rate yang telah di publish pada website resmi Bank Indonesia dengan periode Januari 2010 hingga Desember 2015.

3. Rate of Profit $\left(\mathrm{X}_{3}\right)$

Merupakan alat yang digunakan untuk menilai aset keuangan. Rate of profit merupakan kunci penting bagi bank syariah guna terciptanya keadilan ekonomi bagi pendapatan investasi dan kesejahteraan masyarakat dibandingkan dengan menggunakan sistem bunga. Rate of profit dalam penelitian ini diperoleh dari laporan Statistik Perbankan Syariah yang telah di publish pada website resmi SPS dengan periode Januari 2010 hingga Desember 2015.

4. Deposito Bank Syariah (Y)

Deposito adalah simpanan pihak ketiga pada bank yang penarikannya dapat dilakukan hanya sesudah jangka waktu tertentu menurut perjanjian antara pihak ketiga dan bank yang bersangkutan. Data depsito bank syariah dalam penelitian ini diperoleh dari laporan Statistik Perbankan Syariah dengan periode Januari 2010 hingga Desember 2015.

\section{Jenis dan Sumber Data}

Data yang digunakan dalam penelitian ini adalah data sekunder dan termasuk data time series. Data pada penelitian ini diperoleh dari laporan Badan Pusat Statistik yang telah di publish dalam www.bps.go.id dan data sekunder yang diperoleh dari Statistik Perbankan Syariah yang diterbitkan di www.ojk.go.id yang diambil dalam periode Januari 2010-Desember 2015.

\section{Populasi dan Sampel}

Populasi dalam penelitian ini adalah Bank Umum Syariah di Indonesia. Data yang digunakan sebagai sampel dalam penelitian ini adalah data time series dalam bentuk bulanan yaitu periode Januari 2010 sampai dengan Desember 2015. Metode pemilihan sampel yang digunakan dalam penelitian ini adalah metode pemilihan sampel non acak (non probability sampling) secara purposive sampling.

\section{Teknik Analisis Data}

Metode analisis data yang digunakan dalam penelitian ini adalah dengan metode analisis Regresi Linier Berganda. Dalam melakukan analisis regresi linier berganda, metode ini mensyaratkan untuk melakukan uji asumsi klasik agar mendapatkan hasil regresi yang baik (Ghozali, 2005).

\section{Uji Linieritas}

Uji linieritas adalah suatu prosedur yang digunakan untuk mengetahui status linier atau tidak suatu distribusi data penelitian

\section{Analisis Regresi Linier Berganda}

Dalam penelitian ini, data yang telah dikumpulkan dianalisis dengan menggunakan analisis regresi berganda dengan persamaan kuadrat terkecil biasa atau Ordinary Least Square (OLS). Persamaan regresi yang dibentuk adalah sebagai berikut:

$$
\mathrm{Y}=\mathrm{a}+\mathrm{b}_{1} \mathrm{X}_{1}+\mathrm{b}_{2} \mathrm{X}_{2}+\mathrm{b}_{3} \mathrm{X}_{3}+\mathrm{b}_{4} \mathrm{X}_{4}+\mathrm{e}
$$


Dimana:

$\begin{array}{ll}\mathrm{Y} & \text { : Deposito Bank Syariah } \\ \mathrm{a} & \text { : Konstanta } \\ \mathrm{b}_{1} & \text { : Slope } \\ \mathrm{X}_{1} & \text { : Indeks Harga Konsumen } \\ \mathrm{X}_{2} & \text { : Interest Rate } \\ \mathrm{X}_{3} & \text { : Rate of Profit } \\ \mathrm{e} & \text { : Residual }\end{array}$

\section{Uji Asumsi Klasik}

1. Uji Heteroskedastisitas

Uji heterokedastisitas merupakan uji yang digunakan apakah dalam sebuah model regresi terjadi ketidaksamaan varians dari residual dari satu pengamatan ke pengamatan yang lain. Uji gejala heterokedastisitas juga dapat diketahui dengan menggunakan scatter analisis. Jika titik - titik menyebar dan tidak membentuk pola yang khas maka uji regresi tidak terkena asumsi heteroskedastis.

2. Uji Multikolinearitas

Uji Multikolonieritas bertujuan untuk mengetahui apakah model regresi masing-masing variabel bebas (independen) saling berhubungan secara linier. Model regresi yang baik adalah yang tidak terdapat korelasi linier/hubungan yang kuat antara variabel. Jika nilai Variance Inflating Factor (VIF) lebih dari 10 dan tolerance value kurang dari 0,1 maka terjadi multikolinearitas dan jika nilai Variance Inflating Factor (VIF) kurang dari 10 dan tolerance value lebih dari 0,1 maka tidak terjadi multikolinearitas.

\section{Uji Autokorelasi}

Uji asumsi autukorelasi bertujun untuk menguji apakah dalam suatu model regresi linier ada korelasi antara kesalahan pengganggu pada periode $t$ dengan kesalahan pengganggu pada periode t-1 (Ghozali, 2005:95). Pengambilan keputusan ada tidaknya autokorelasi, sebagai berikut:

a. Jika $0<\mathrm{d}<\mathrm{dl}$, maka tidak ada autokorelasi positif b. Jika $\mathrm{dl} \leq \mathrm{d} \leq \mathrm{du}$, maka tidak ada autokorelasi positif

c. Jika 4-dl $<\mathrm{d}<4$, maka tidak ada autokorelasi negatif

d. Jika 4 -du $\leq \mathrm{d} \leq 4$-dl, maka tidak ada autokorelasi negatif.

\section{Uji Hipotesis}

1. Uji F

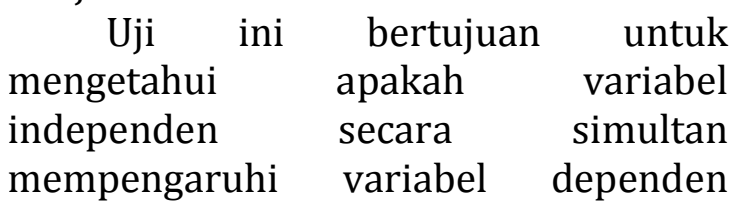
secara signifikan. Jika F hitung $>\mathrm{F}$ tabel berarti Ho ditolak dan Jika $\mathrm{F}$ hitung $<\mathrm{F}$ tabel berarti Ho diterima.

2. Uji t

Uji $t$ digunakan untuk mengukur seberapa jauh pengaruh satu variabel independen secara individual dalam menerangkan variasi variabel dependen. Jika $t$ hitung $>t$ tabel berarti Ho ditolak dan Jika $t$ hitung $<\mathrm{t}$ tabel berarti Ho diterima.

3. Uji $\mathrm{R}^{2}$

Uji R2 pada intinya mengukur seberapa jauh kemampuan model dalam menerangkan variasi variabel dependen. Nilai koefisien determinasi adalah antara nol dan satu.

\section{HASIL DAN PEMBAHASAN}

\section{Uji Asumsi Klasik}

1. Uji Linieritas

Hasil uji linieritas ditunjukkan oleh tabel 1.

Tabel 1

\section{UJI LINIERITAS}

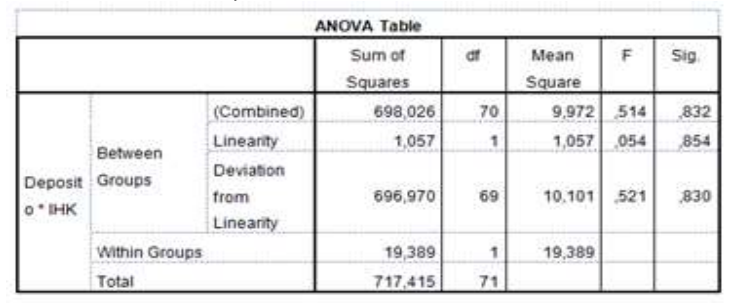

Berdasarkan nilai Sig. Deviation From terlihat bahwa nilainya lebih dari 0,05 , sehingga dapat disimpulkan bahwa terdapat hubungan linier antar variabel. 
2. Uji Multikolinearitas

Hasil uji multikolinearitas ditunjukkan oleh tabel 2.

Tabel 2

UJI MULTIKOLINEARITAS

\begin{tabular}{|c|c|c|}
\hline \multirow{2}{*}{ Variabel } & \multicolumn{2}{|c|}{ Colliniearidy Statistic } \\
\cline { 2 - 3 } & Tolerance & VIF \\
\hline IHK & 0,529 & 1,891 \\
\hline Interest Rate & 0,705 & 1,418 \\
Rate of Profit & 0,707 & 1,415 \\
\hline
\end{tabular}
variabel IHK, Interest Rate dan Rate of Profit terlihat bahwa nilai VIF lebih kecil dari 10, sehingga dapat disimpulkan bahwa model regresi terbebas dari multikolinieritas.

\section{Uji Autokolerasi}

Hasil uji autokolerasi ditunjukkan oleh tabel 3.

TABEL 3

\section{UJI AUTOKORELASI}

\begin{tabular}{|l|r|r|r|r|r|}
\hline Model & $R$ & $R$ Square & $\begin{array}{c}\text { Adjusted } R \\
\text { Square }\end{array}$ & $\begin{array}{c}\text { Std. Error of the } \\
\text { Estimate }\end{array}$ & Durbin-Watson \\
\hline 1 & $423^{\circ}$ &, 179 &, 142 & 2,94371 & 1,962 \\
\hline
\end{tabular}

Model regresi dikatakan bebas dari masalah autokorelasi apabila nilai durbin-watson diantara -2 hingga +2 . Berdasarkan ouput SPSS terlihat bahwa nilai DW sebesar 1,962 dan terletak diantara -2 dan +2 , sehingga dapat disimpulkan bahwa model regresi tersebut terbebas dari masalah autokorelasi.

3. Uji Heteroskedastisitas

Hasil uji heteroskedastisitas akan ditunjukkan oleh gambar berikut.

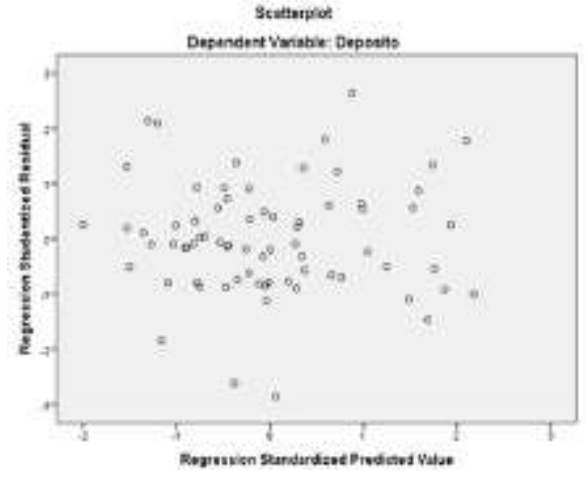

Berdasarkan gambar tersebut titik-titik data tersebut menyebar dan tidak membentuk pola tertentu sehingga dapat disimpulkan bahwa dalam data tersebut tidak terjadi heteroskedastisitas.

4. Uji Normalitas

Hasil uji normalitas akan ditunjukkan oleh gambar 2 berikut.

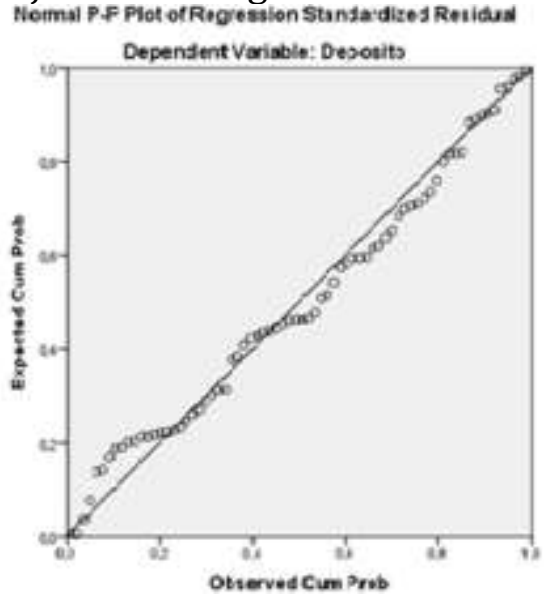

Gambar 2

\section{P-P PLOT Uji Normalitas}

Berdasarkan gambar 2 menunjukkan distribusi normal karena lingkaran-lingkaran kecil menyebar di sekitar garis diagonal dan mengikuti arah garis diagonal.

\section{Analisis Koefisien Determinasi Berganda}

Nilai koefisien determinasi berganda dapat diketahui dari tabel 4 berikut ini.

TABEL 4

Hasil Koefisien Determinasi Berganda

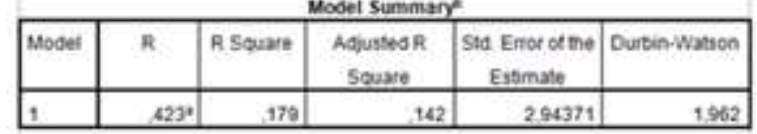

Berdasarkan tabel 4.18 terlihat bahwa R2 sebesar 0,179 atau 17,9\% artinya variabel Indeks Harga Konsumen, Interest Rate, dan Rate of Profit dapat menjelaskan variabel dependen yaitu deposito bank syariah sebesar $17,9 \%$ sedangkan sisanya sebesar $82,1 \%$ dijelaskan oleh variabel lain yang tidak dimasukkan ke dalam model regresi. 
Analisis Regresi Linier Berganda

Nilai regresi linier berganda dapat diketahui dari table 5 berikut ini

TABEL 5

ANALISIS REGRESI BERGANDA

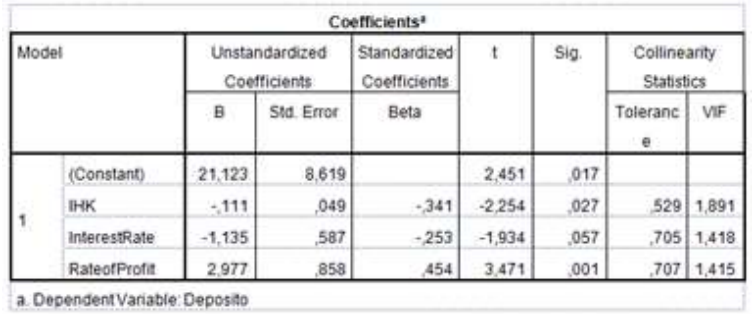

Berdasarkan hasil dari tabel 5 maka persamaan regresi linier berganda dapat diperoleh sebagai berikut:

$Y=21,123-0,111\left(x_{1}\right)-1,135\left(x_{2}\right)+$ $2,977\left(\mathrm{x}_{3}\right)+\mathrm{e}$

Uji F

Hasil uji F ditunjukkan oleh tabel 6 berikut ini

TABEL 6

UJI F

\begin{tabular}{|c|c|c|c|c|c|c|}
\hline \multicolumn{7}{|c|}{ ANOVA $^{\circ}$} \\
\hline Mo & & Sum of Squares & $d f$ & Mean Square & $\mathrm{F}$ & Sig. \\
\hline \multirow{3}{*}{1} & Regression & 128,165 & 3 & 42,722 & 4,930 & $.004^{\circ}$ \\
\hline & Residual & 589,250 & 68 & 8.665 & & \\
\hline & Total & 717,415 & 71 & & & \\
\hline
\end{tabular}

Berdasarkan tabel 6 dapat disimpulkan bahwa IHK, Interest Rate, dan Rate of Profit berpengaruh signifikan terhadap Deposito Bank Umum Syariah di Indonesia.

Uji t

TABEL 6

UJI t

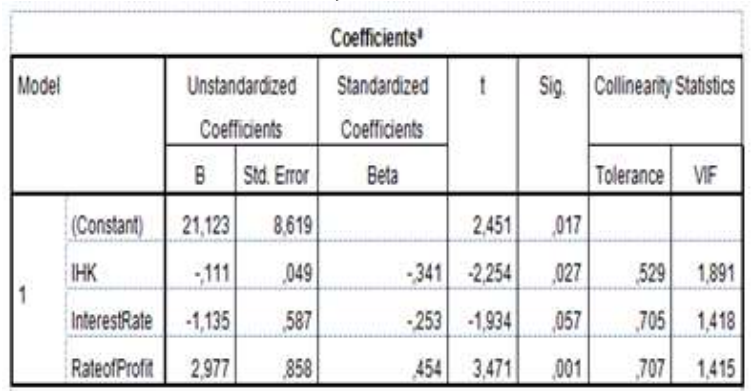

Berdasarkan table 6 tersebut, maka pengujian terhadap hipotesis pengaruh masing-masing variabel independen terhadap variabel dependen dapat dijelaskan sebagai berikut:

1. Hasil uji $\mathrm{t}$ berdasarkan nilai signifikansi yang diperoleh variabel Indeks Harga Konsumen sebesar 0,027 yang mana lebih kecil dari nilai $\alpha$ yang telah di tentukan yakni sebesar 0,05, maka dapat disimpulkan bahwa Indeks Harga Konsumen memiliki pengaruh signifikan terhadap Deposito Bank Syariah secara parsial.

2. Variabel Interest Rate memiliki pvalue uji t lebih besar dari $\alpha(0,057>$ 0,05), sehingga Ho diterima. Kesimpulan yang dapat diperoleh adalah Interest Rate berpengaruh tidak signifikan terhadap Deposito Bank Umum Syariah di Indonesia secara parsial.

3. Variabel Rate of Profit memiliki pvalue uji t lebih kecil dari $\alpha(0,001<$ 0,05), sehingga Ho diterima. Kesimpulan yang dapat diperoleh adalah Rate of Profit berpengaruh signifikan terhadap Deposito Bank Umum Syariah di Indonesia.

Pengaruh Indeks Harga Konsumen, Interest Rate, dan Rate of Profit Secara Simultan Terhadap Deposito Bank Umum Syariah di Indonesia

Hasil penelitian ini menunjukkan bahwa Indeks Harga Konsumen, Interest Rate, dan Rate of Profit secara simultan berpengaruh signifikan terhadap Deposito Bank Umum Syariah di Indonesia. Hal ini terlihat dari p-value uji F lebih kecil dari $\alpha(0,004<0,05)$, sehingga HO ditolak dan dapat disimpulkan bahwa variabel Indeks Harga Konsumen, Interest Rate, dan Rate of Profit secara simultan berpengaruh signifikan terhadap Deposito Bank Umum Syariah di Indonesia. Hal ini menunjukkan bahwa setiap Bank Umum Syariah harus tetap melihat faktor internal yaitu Rate of Profit dan faktor eksternal yaitu IHK dan Interest Rate untuk meningkatkan 
nasabah dalam menempatkan dananya pada Bank Syariah.

\section{Pengaruh Indeks Harga Konsumen Terhadap Deposito Bank Syariah}

Pengaruh IHK terhadap Deposito Bank Syariah secara parsial dapat dilihat dari hasil pengujian hipotesis dengan uji t. Hasil dari pengolahan data, terlihat bahwa p-value dari IHK lebih kecil dari $\alpha(0,027>0,05)$, sehingga H0 ditolak. Kesimpulan yang dapat diambil IHK berpengaruh signifikan terhadap Deposito Bank Umum Syariah di Indonesia secara parsial. Indeks Harga Konsumen dalam penelitian ini berpengaruh signifikan dan bernilai negatif. Hal ini menunjukkan jika Indeks Harga Konsumen mengalami kenaikan maka Deposito Bank Syariah akan mengalami penurunan. Hasil penelitian ini berbeda dengan hasil penelitian dari Zainal et al (2009) yang menjelaskan bahwa Indeks Harga Konsumen memiliki hubungan signifikan terhadap deposito mudharabah. Yang membedakan hasil penelitian ini dengan penelitian sebelumnya terletak pada faktor kondisi ekonomi negara Indonesia dan Malaysia dan juga dapat dipengaruhi oleh minat masyarakat untuk menabung yang berbeda. Jadi meskipun IHK sedang meningkat di Malaysia masyarakatnya masih tetap tinggi untuk menempatkan dananya pada bank dalam bentuk deposito.

\section{Pengaruh Interest Rate Terhadap Deposito Bank Syariah}

Pengaruh Interest Rate terhadap Deposito Bank Syariah secara parsial dapat dilihat dari hasil pengujian hipotesis dengan uji t. Hasil dari pengolahan data, terlihat bahwa p-value dari Interest Rate lebih besar dari $\alpha$ $(0,057>0,05)$, sehingga HO diterima. Kesimpulan yang dapat diambil adalah Interest Rate berpengaruh tidak signifikan terhadap Deposito Bank Syariah secara parsial. Berdasarkan hasil dari uji t yang diperoleh bahwa
Interest Rate secara parsial tidak signifikan hal tersebut dapat dipengaruhi oleh beberapa faktor. Haron (2000) menjelaskan bahwa faktor yang dapat mempengaruhi nasabah dalam memilih menempatkan dananya pada bank syariah karena adanya doktrin agama atau faktor kepercayaan.

\section{Pengaruh Rate of Profit Terhadap Deposito Bank Syariah}

Pengaruh Rate of Profit terhadap Deposito Bank Syariah secara parsial dapat dilihat dari hasil pengujian hipotesis dengan uji t. Hasil dari pengolahan data, terlihat bahwa p-value dari Rate of Profit lebih kecil dari $\alpha$ $(0,001>0,05)$, sehingga H0 ditolak. Kesimpulan yang dapat diambil adalah Rate of Profit berpengaruh signifikan terhadap Deposito Bank Syariah secara parsial. Hasil dari penelitian ini sama dengan hasil penelitian yang dilakukan oleh Haron dan Ahmad (2000) yang menjelaskan bahwa rate of profit berpengaruh signifikan positif terhadap deposito bank syariah sehingga apabila rate of profit mengalami kenaikan maka deposito pada bank syariah juga mengalami kenaikan.

\section{KESIMPULAN DAN IMPLIKASI}

Berdasarkan hasil analisis dan pembahasan pada bab sebelumnya, maka dapat disimpulkan sebagai berikut :

1. Indeks Harga Konsumen secara parsial berpengaruh signifikan negatif terhadap dana deposito bank umum syariah di Indonesia.

2. Interest Rate secara parsial berpengaruh tidak signifikan terhadap dana deposito bank umum syariah di Indonesia.

3. Rate of Profit secara parsial memiliki pengaruh yang signifikan terhadap dana deposito bank umum syariah di Indonesia. 
4. Indeks Harga Konsumen, Interest Rate, dan Rate of Profit secara simultan berpengaruh terhadap dana deposito bank umum syariah di Indonesia.

Saran yang dapat diberikan dari penelitian ini adalah:

1. Bagi Bank Umum Syariah di Indonesia disarankan untuk lebih meningkatkan keuntungan dan pelayanan bagi nasabah karena telah terbukti bahwa nasabah telah banyak yang mempercayakan dananya pada bank syariah saat ini sehingga apabila faktor keuntungan, pelayanan dan fasilitas yang lebih baik bukan tidak mungkin akan lebih banyak lagi nasabah yang menempatkan dananya pada bank syariah. Dan juga Bank Umum Syariah di Indonesia bisa lebih mengedukasi dari segi maslahah sehingga bisa menarik minat umat islam untuk menempatkan dananya pada bank syariah.

2. Bagi masyarakat berdasarkan hasil penelitian disarankan untuk masyarakat umum khususnya umat muslim untuk menempatkan atau menyimpan dananya pada bank syariah karena bank syariah juga tidak kalah menguntungkan dari bank konvensional dan jika kita menempatkan dana pada bank syariah akan membawa hati kita tentram karena terhindar dari unsur riba dan menggunakan prinsip syariah islam yang diawasi oleh Dewan Syariah Nasional.

3. Untuk penelitian selanjutnya dapat melanjutkan penelitian ini dengan objek penelitian bukan bank umum syariah tetapi masing-masing bank syariah yang ada di Indonesia. Dan juga dapat menggunakan variabelvariabel lain yang dapat mempengaruhi dana deposito bank umum syariah di Indonesia.

\section{DAFTAR PUSTAKA}

Adiwarman, Karim, dan Afif, Adi, Zakaria, 2005. Islamic Banking in Indonesia: a Qualitative Approach. 6th Conference On Islamic Economics and Finance. Jakarta, Indonesia, p.52

Antonio, Syafii. 2001. Bank Syariah Dari Teori Ke Praktik. Jakarta: Gema Insani

Ascarya, 2012."Alur Transmisi dan Efektivitas Kebijakan Moneter Ganda di Indonesia, Jurnal Ekonomi dan Perbankan. , volume 14 Nomor 3 Januari 2012 hal 5. Diakses tanggal 17 November 2013 Pukul 19.35 WIB

Boediono. 1998. Ekonomi Moneter. Yogyakarta: BPFE

Dewan Syariah Nasional. 2000. Fatwa DSN No: 03/DSN-MUI/IV/2000 tentang Deposito. (Online) www.dsnmui.or.id, diakses pada 18 September 2016. (Online) www.dsnmui.or.id, diakses pada 18 September 2012

Dendawijaya, Lukman. 2001. Manajemen Perbankan. Jakarta: Ghalia Indonesia

Departemen Agama RI. 2004. Mushaf AlQur'an dan Terjemahnya Revisi tahun 2004. Jakarta: DEPAG RI

Eriemo, Nathanael O. 2014. Macroeconomic Determinants of Bank Deposit in Nigeria, Journal of Economic and Sustainable Development ISSN 222-1700 (Paper) ISSN 2222-2855 (Online) Vol. 5, No. 10, 2014

Ghozali, Imam. 2005. Aplikasi Analisis Multivariate dengan Program SPSS, Semarang: Badan Penerbit Universitas Diponegoro

Haron, S. and Ahmad, N. "The effects of conventional interest rates and rate of profits on funds deposited with Islamic banking system in Malaysia", International Journal of 
Islamic Financial Services, Vol. 1 No. 4, 2000, h. 1-7.

Mankiw, N.Gregory. 2000. Teori Makro Ekonomi. Jakarta: Erlangga

Sunariyah. 2004. Pengantar Pengetahuan Pasar Modal. Edisi keempat. Yogyakarta: Penerbit UPP-AMP YKPN

Supriyanto, Trisaldi. 2015. Konsep Rate of Profit dan Profitabilitas Ekonomi Perbankan Syariah.

Zainal, N, S., Yusuf, Z, M., \& Jusoff, K. 2009. Influence of Economic Factors on Performance of Investment and Mudharabah Accounts in Maybank, Malaysia. International Journal of Economics and Finance, Vol. 1 No. 2, August 2009

www.bi.go.id

www.bps.go.id 